\title{
Task 3.14 - Demonstration of Technologies for Remote Power Generation in Alaska
}

\section{Semi-Annual Report July 1 - December 31, 1995}

RECEIVED

AUG 111997

OSTI

Work Performed Under Contract No.: DE-FC21-93MC30097

For

U.S. Department of Energy

Office of Fossil Energy

Federal Energy Technology Center

Morgantown Site

P.O. Box 880

Morgantown, West Virginia 26507-0880

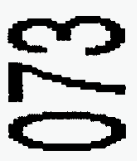

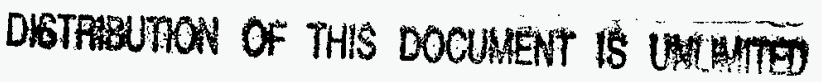

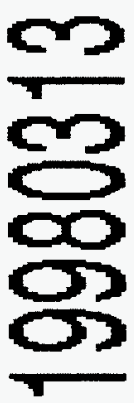

By

Energy \& Environmental Research Center

University of North Dakota

15 North 23rd Street

P.O. Box 9018

Grand Forks, North Dakota 58202-9018 


\section{Disclaimer}

This report was prepared as an account of work sponsored by an agency of the United States Government. Neither the United States Government nor any agency thereof, nor any of their employees, makes any warranty, express or implied, or assumes any legal liability or responsibility for the accuracy, completeness, or usefulness of any information, apparatus, product, or process disclosed, or represents that its use would not infringe privately owned rights. Reference herein to any specific commercial product, process, or service by trade name, trademark, manufacturer, or otherwise does not necessarily constitute or imply its endorsement, recommendation, or favoring by the United States Government or any agency thereof. The views and opinions of authors expressed herein do not necessarily state or reflect those of the United States Government or any agency thereof. 
TABLE OF CONTENTS

INTRODUCTION

.1

OBJECTIVES

.1

ACCOMPLISHMENTS

1

FUTURE WORK

.3

i 


\section{TASK 3.14 - DEMONSTRATION OF TECHNOLOGIES FOR REMOTE POWER GENERATION IN ALASKA}

\section{INTRODUCTION}

In over 165 villages in Alaska, the use of local fossil fuel supplies or renewable energy resources could greatly reduce the cost of electricity and space heating. Currently, the diesel generators are the most commonly used electrical generating systems; however, the high fuel costs result in extremely high electrical power costs relative to the lower 48 states. The reduction of fuel costs associated with the use of indigenous, locally available fuels running modular, high-efficiency power-generating systems would be extremely beneficial.

\section{OBJECTIVES}

The overall goal of this project is a site-specific demonstration of a small, environmentally acceptable electric generating system fueled on indigenous fuels and waste materials to serve the microgrid or stand-alone power distribution systems typical of remote, isolated Alaska Native communities.

The objective of the project is to develop a commercialization plan that includes an analysis of the quantity, quality, and cost of the available fuels; a mapping of the electricity and district heating needs of a selected community, including electrical distribution layout and interconnecting steam piping; a step-by-step review of the environmental regulations and permit applications that need to be met; and a preliminary design and budget for the demonstration of a $0.5-$ to $6-\mathrm{MWe}$ power system to be completed by the Energy \& Environmental Research Center (EERC) in a manner that provides technical and regulatory readiness to proceed with implementation of the demonstration.

The scope of work is divided into two phases. The first phase will involve a workshop to provide input for the final definition of the technology to be demonstrated and the selection of a study site, followed by process design verification studies as needed (e.g., combustion tests on candidate fuels). The second phase of the work will develop the preliminary engineering design and provide the engineering, economic, and regulatory information necessary to proceed with the full demonstration. Parallel work will be conducted as needed to support the demonstration of other power technologies for additional remote sites.

\section{ACCOMPLISHMENTS}

A workshop held in September 1995 entitled "Alaska Native, American Indian, and Native Hawaiian Remote-Site Power Generation Workshop: Transferring the Alaskan Experience," built upon the Small Power Generation Workshop held in Anchorage, Alaska, in May 1994. Alaska Natives, state officials, and representatives from industry, universities, and the U.S. Department of Energy (DOE) discussed the energy needs of indigenous villages at the 1994 workshop and identified the most suitable energy options to meet those needs. Since that time, projects have 
progressed to demonstrate these small, easy-to-operate-and-maintain, environmentally friendly, and economically acceptable technologies, which use indigenous fuels and waste materials to produce electricity and heat. The objectives of the 1995 workshop were:

- To share the results of activities undertaken to meet the energy needs of remote villages in Alaska.

- To facilitate development of those ongoing projects in Alaska so that viable projects can continue through the demonstration phase.

- To explore the opportunities that exist to commercialize the technologies and transfer the related information to other indigenous communities.

Prior to and since the first Alaskan workshop in 1994, the Alaskan community has proceeded with site and technology evaluations for locating alternative power-generating systems in Alaska. Doyon Corporation, operating under a Cooperative Research and Development Agreement (CRADA) with the DOE Morgantown Energy Technology Center is evaluating a fluidized-bed combustion (FBC) steam-generating system for possible installation at McGrath. The Division of Community and Regional Affairs (DCRA), in conjunction with Alaska Power and Telephone, has identified Tok as a potential site for a fluidized-bed combustor (FBC) for production of electricity and heat and are pursuing that option. Through a grant from DOE, the College of West Virginia is pursuing utilizing coal bed methane to fire a fuel cell at Chignik Lagoon. Other options and sites also continue to be investigated. The results from this ongoing work were reviewed at the workshop as a way to emphasize the site-specific opportunities that exist for demonstrating small generating systems in Alaska.

As a result of the first workshop, a number of criteria were identified as requirements for technologies that would be considered for an initial project in Alaska. The criteria include broad community benefits, such as:

- The economic supply of electricity and heat.

- The enhancement of health and environment.

- Economic development leading to job creation and infrastructure development.

During the 1995 workshop, an overview of those technologies currently being considered for initial demonstration projects was presented. These included FBC coupled with either a steam or hot-air gas turbine, fuel cells, and a variety of renewable energy options. The technologies were ranked against a set of criteria developed during the 1994 workshop from needs of the Alaskan communities. For the nonrenewable options, fuel availability is an issue since no coal mines or gas wells exist. Siting and cost are the main barriers that exist to the renewable energy sources. Based on the technical evaluation performed, fluid-bed combustion is the best solid fuel option for remote power generation, while fuel cells offer the best potential for utilizing natural gas or coal bed methane. These technologies are recommended for demonstration. Ongoing studies are evaluating the cost of implementing these technologies in several communities in Alaska. Full proceedings of the 1995 workshop are available. 


\section{FUTURE WORK}

The end goal of the Remote-Site Power Development and Demonstration Project is the demonstration of remote-site power options in Alaska. Work has started down that path through the activities of the various groups in Alaska with assistance from DOE. The EERC is providing assistance to these groups to catalyze the demonstration efforts. Currently, the EERC and its partners are working to complete a modular design to sufficient details to permit the subsequent financing and construction of the demonstration facilities. Once this phase of the project is completed, final decisions to proceed with the installation of the demonstrations can be made. It is anticipated that three demonstrations-an FBC with an air turbine at Tok, an FBC with a steam turbine at McGrath, and a coal bed methane-fired cell at Chignik Lagoon-will proceed to a full demonstration as a result of these efforts.

The Alaskan initiative to demonstrate these "appropriate technologies" in Alaska has the potential to greatly accelerate their movement along the commercialization pathway. The demonstrations in remote regions in Alaska, under similar conditions to those that exist in many other locations throughout the world, will provide the proof that the technologies can meet the power requirements of remote sites. In addition to developing the necessary data to define the costs and performance of these systems at other sites, the demonstrations will result in the formation of teams of people and organizations that have the capabilities to deploy the technologies aon a global basis. 
M97005450

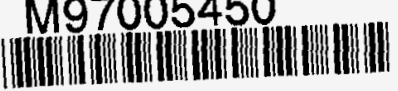

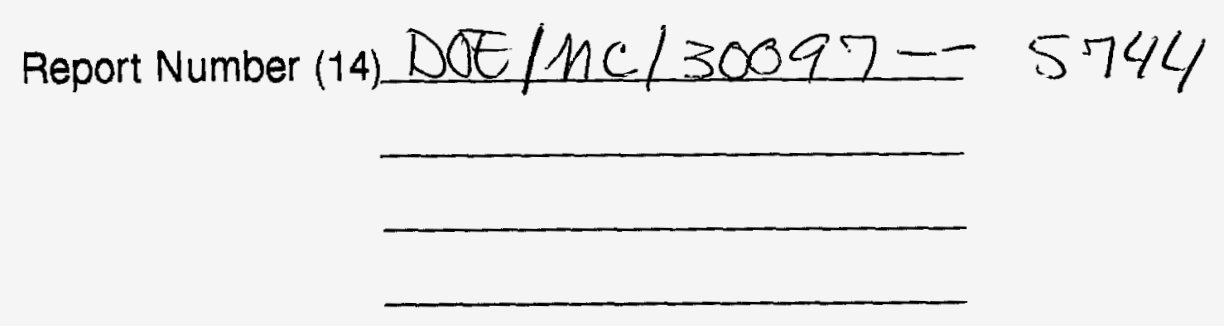

دubl. Date (11) 1997 Q8

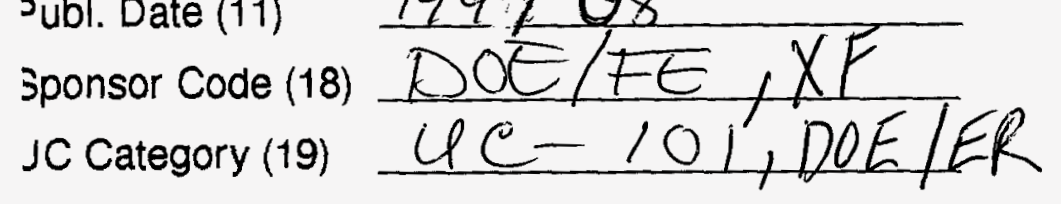

DOE 